\title{
Data Research of the Whole Life Cycle Project Cost Information Sharing
}

\author{
Huashan Wang \\ School of Management, Tianjin University of Technology, Tianjin 300384, China
}

\begin{abstract}
According to the characteristics of the engineering cost information flow in the whole life cycle, Design the project cost index system of the original data and analysis data, Collecting, sorting, analysis, calculates the project cost information, Estimate the whole life cycle engineering cost of the proposed project refer to the project cost to share information. Through the above analysis, Combined with the cost management and computer information technology, Build the project cost information data management model, Cost management participants share the information resources with the help of engineering cost information platform. Implements the beforehand, active and dynamic management of engineering cost in the total project life cycle. KEYWORD: The project cost; Information data sharing; Full life cycle; Computer technology
\end{abstract}

\section{INTRODUCTION}

Along with social economy development, Construction projects become more large, more complicated, more systematic. The engineering cost management become more and more difficult, in the engineering project management. Under the existing project management mode, Construction project decision-making, project design, project implementation, project operation is independent of each other. All these factors result in each stage, various department's communication inefficient, and Information flow barriers. The result is bad for the whole life cycle to supervise and control the project cost. Therefore, many countries try to apply information technology to engineering cost management. Professionals hope to be able to enhance the level of project cost management. Leland Stanford Junior University established CIFE (Center for integrated Facility Engineering) in 1989, purpose is to carry out the study of engineering project management informatization. By the end of the 20th century, The United States has created a new project management mode based on the Web. UK research institutions also developed BCIS (Building Cost Information Service). This software is used in the project cost analysis, cost index analysis, price management and cost control. It can analysis the existing engineering cost index and price information to estimate the cost index and index of new construction. In our country, the ministry also formulated The construction project cost information management method (exposure draft) (Shibo Dong et al, 2005).
National policy stressed that China should set up the project cost information database. By engineering cost information platform and website, collect construction projects information data of new technology, new craft, and new material. And to carry out data exchange and sharing of professional services about Engineering cost information index, index and price information (Bing Feng et al, 2005).

In the practical work, To put the project cost information into the computer system is not equal to realize the informatization of project cost management, breaking the information island is the key to realize the project cost management informationization (Dong Jin et al, 2009). On the one hand, we should take advantage of the information technology to strengthen the analysis, processing and exchange of information. Create a model to classify, summary and analysis data of engineering cost information. On the other hand, we should break the bondage of departments and stage. Actively explore the new mode of engineering cost management under the condition of informatization. In this paper, the whole life cycle engineering cost information data sharing is a starting point, To explore the change rule of the project cost information at each stage. To explore the the new ways of collection, statistics, analysis, about engineering cost information. Enhance the level of project cost information management, and provide the beneficial reference. 


\section{WHOLE LIFE CYCLE ENGINEERING COST INFORMATION}

\subsection{Whole life cycle engineering cost information flow}

Whole life cycle engineering cost information system is a dynamic loop. In this article, Engineering cost was design for the feed-forward information flow, information flow among and information flow after the feed stream. Feedforward information refers to the same or similar completed project whole life cycle cost, we can use the information for similar engineering cost management for guidance. Information flow among is for the cost of the project information in real time to collect and process control, In view of the ongoing projects. It can be real-time monitoring of the current project cost. Information flow after the feed stream is a kind of overall feedback and correction to the whole life cycle cost management. It can Modify index and parameters about the project cost information database (Lu Yu et al, 2013).

Three kinds of information flow is restraining each other, interdependent, the former is the target basis of the latter, and the latter is the former elaboration and supplement. With the progress of the project, the project cost information from abstract to concrete.

\subsection{Engineering cost information management mode}

Whole life cycle engineering cost data management using the unified under centralized and decentralized management mode, it will gradually form run jointly by the state, industry, local mode. The local competent department of construction and engineering cost management institutions should collect raw data of Single items of projects, unit and division of the project in the professional field. They can provide summary data about the project cost; Industry department in charge of construction and engineering cost management institutions can collect, identify, statistics, analysis and measurement engineering information of same and similar projects. And the related project cost data report to the competent department of national construction. The project cost information data includes: the unit cost, the unit consumption and change trend of the main building materials and equipment. Specific content as shown in figure 1 .

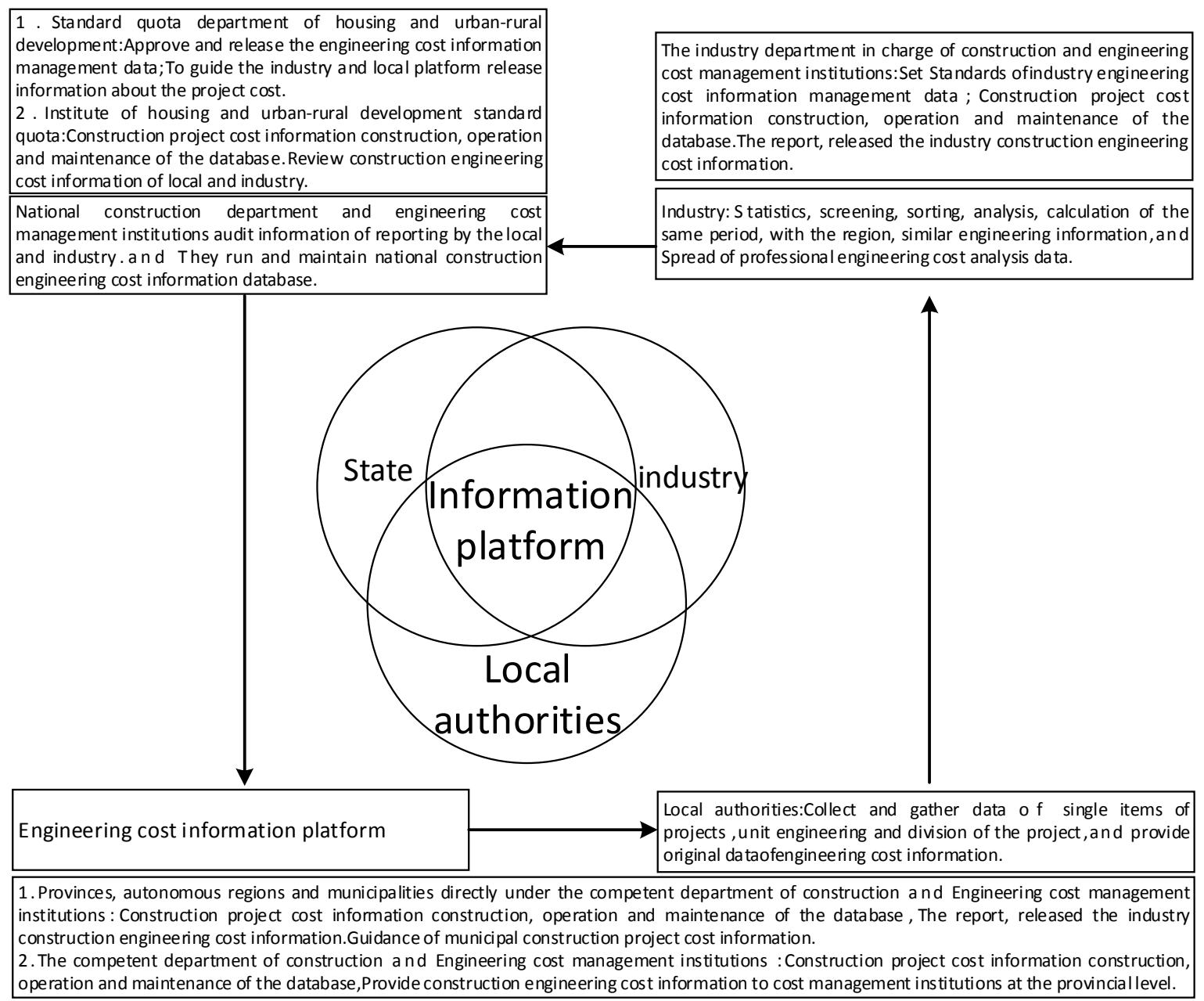

Figure 1 Engineering cost information management mode 
Engineering cost consultation enterprises and personnel shall be in accordance with the relevant regulations, timely and accurately report the consultation results file. Construction of the parties shall fill in the project cost information based on the principle of timely, true and complete. Engineering cost management department shall report the outcome document as the basis of assessment. Share database resources base on the principle of reciprocity.

\subsection{The index system of project cost sharing information data}

The characteristics of the engineering cost information data is large amount of information, strong regional and timeliness. Therefore, timely and accurate information collecting engineering cost data is the core and the key of the construction of index system. Whole life cycle engineering cost information database is a combination of all kinds of data, accordance with the professional and the project. It includes the original data and analysis data. The project cost information data can be divided into general and special data according to use standard. It can also be divided into index information, price information, index, according to the reaction of content. This article main component raw data and analysis data of the project cost information database.

Table 1. Project cost sharing information data index system design

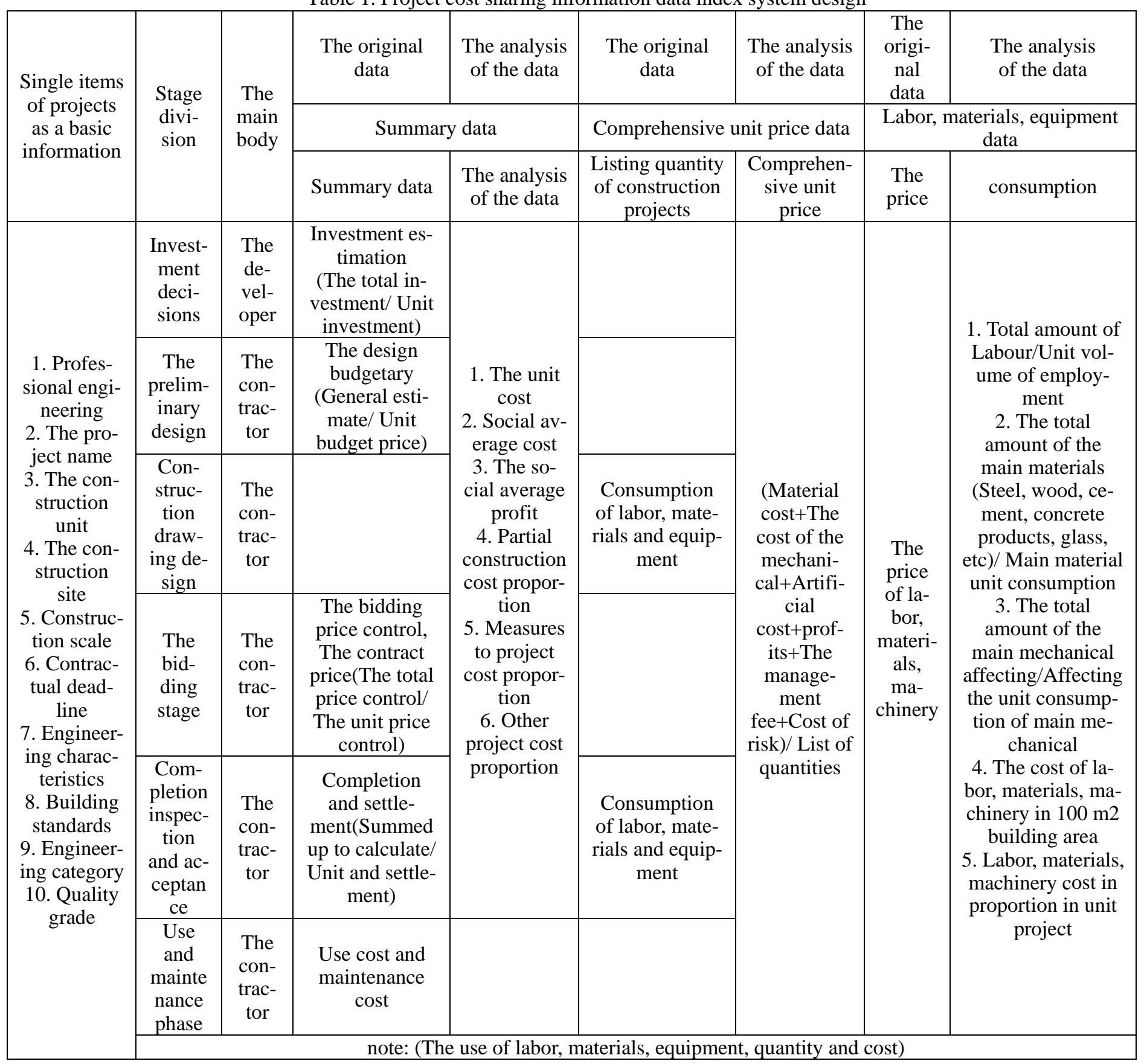


The project cost information data index system of the single items of projects as a design object. First of all, the classification and coding of the construction engineering based on single items of projects as a basic information. Basic information is the main characters of the construction project cost factors, it includes basic overview and technical economic conditions of single project. The basic information of the single projects includes: Professional division, name of the project, the construction unit, construction site, construction scale, contractual deadline, engineering characteristics, category, building standards, quality grade, etc. The professional engineering is divided into building, decoration engineering, installation, municipal engineering, landscape engineering and mining engineering and so on six secondary indicators. Engineering characteristics mainly describe the type and structure type. Building standards including building factory, building overall width, total height and architectural decoration standards (Qin Lin, 2005).

To have to recruit bid construction project, the employer and the contractor shall sign the construction project construction contract first. The developer to submit the project cost in the contract information to local engineering cost management institutions. And it will be dealt with the basis of a construction permit. The contractor recognize settlement documents submitted to the local engineering cost management institutions, and it will be dealt with the basis of the completion acceptance. The index system of project cost sharing information data design as shown in table 1.

Industry department in charge of construction and engineering cost management institutions to the original, the summary of the project cost data for statistics, sorting, analysis and calculation. On the same project longitudinal monitoring and early warning. Longitudinal monitoring analysis indicators as shown in table 2. Lateral comparison and analysis at the same time, with areas and similar engineering projects, as shown in table 3. According to the requirements of the investment estimation accuracy in different stages. And refer to the project investment estimation stage division and the precision requirement (Jie Ni et al, 2013). Specific see table 4 . If the design budgetary estimate of the amount is $20 \%$ above investment estimation, or the contract price is beyond design budgetary estimate of $10 \%$, it needs to be reported for examination and approval department budget and the original examination and approval department, get their approval. If the completion settlement price exceeds 5\% of the contract price, it needs to analyze the cause of cost overruns, and formulate corrective plan, and report to the project examination and approval department.
3 USING THE SHARED PROJECT COST INFORMATION TO ESTIMATE THE COST OF THE PROPOSED CONSTRUCTION PROJECT

Life-cycle engineering cost sharing information is the basis of macro management, project decision-making. It is also a rapid estimation of construction project cost data. The quantitative analysis method of engineering cost information data with fuzzy mathematics method, artificial neural network, statistical regression, support vector method, etc. Fuzzy mathematics method classification including fuzzy clustering method and fuzzy inference system on the application. The fuzzy clustering analysis method is a multivariate analysis method of mathematical statistics.

Quantitative mathematical method is used to determine the sample of the close and distant relationship. Divided objectively thereby engineering cost information data types. Generally include cost, consumption quantity, and three types of information data.

Using the method of construction project investment estimation in the stage of investment, first, we should classify of engineering cost information data. Then choose three similar projects are completed as samples. According to the construction time, construction site, adjust the influence factors of the project. The proposed project and similar projects need to establish the corresponding membership function about similarity degree. Describe and establish the similarity matrix according to membership function between the proposed project and similar projects. Proposed the Euclidean distance between the project $\mathrm{X}$ and similar projects $\mathrm{Y}$ is:

$\mathrm{d}(\mathrm{x}, \mathrm{y})=\sum_{k=1}^{n}\left|u\left(x_{k}\right)-u\left(y_{k}\right)\right|$

In the formula, u-Membership function.

Close to the calculating formula for:

$(\mathrm{x}, \mathrm{y})=\frac{1}{n} \times d(x, y)$

According to the largest degree principle, Selection of the three biggest degree to assess the value of the three most similar of the proposed construction project engineering samples A B C. Regional level of productivity development in our country is different, economic development is not balanced, so the price of labor, materials and mechanical difference is larger. Adjustment coefficient calculation formula about the place is:

$\alpha=\frac{\sum_{i=1}^{n} D_{r i} \times P_{r i}}{\sum_{i=1}^{m} D_{q i} \times P_{q i}}$

In the formula, $D_{n i} \longrightarrow$ Similar project unit price in the region;

$P_{r i} \longrightarrow$ Similar projects were weighted in the local;

$D_{q i}-$ Similar project unit price in other areas;

$P_{q i}-$ Similar projects were weighted in other areas; 
The price adjustment coefficient calculation formula are described below(4):

$\beta=\frac{\sum_{i=1}^{n} D_{r i} \times P_{r i}}{\sum_{i=1}^{m} D_{q i} \times P_{q i}}$

In the formula, $D_{n i} \longrightarrow$ Similar project unit price at this stage;

$P_{r i} \longrightarrow$ Similar projects were weighted at this stage;

$D_{q i}$-Similar project unit price in the base period;

$P_{q i}-$ Similar projects were weighted in the base period;

When other factors existing in the engineering construction, is calculated using the above method can also be adjusted factor. Investment estimation of the proposed construction project unit valuation is:

$$
\begin{aligned}
\mathrm{D}= & {\left[\alpha_{1} \beta_{1} D_{1}+\alpha_{2} \beta_{2} T_{2} D_{2}\left(1-T_{1}\right)+\right.} \\
& \left.\alpha_{3} \beta_{3} T_{3} D_{3}\left(1-T_{1}\right)\left(1-T_{2}\right)\right]+ \\
& \left(\frac{\left(1-T_{1}\right)\left(1-T_{2}\right)\left(1-T_{3}\right)\left(\alpha_{1} \beta_{1} D_{1}+\alpha_{2} \beta_{2} D_{2}+\alpha_{3} \beta_{3} D_{3}\right)}{3}\right)
\end{aligned}
$$

We can estimate and predict the construction project operation and maintenance costs through the analysis of the whole life cycle engineering cost information.

The proposed project whole life cycle engineering cost is:

$$
\begin{aligned}
\mathrm{LCC}= & S^{\prime} \times D+S^{\prime}\left(P W A \sum_{i=1}^{n a r} A_{i}+\right. \\
& \left.\sum_{k=1}^{n a r} C_{k} P W N_{k}+P W S \times S\right)
\end{aligned}
$$

In the formula, $S$ - The architectural area of the proposed project;

$\mathrm{D}$ - The investment estimation of the unit price of the proposed construction project;

PWA_ The discount factor of the annual cycle cost;

nar- The annual cycle of cost;

$\mathrm{C}$ - - The cost of the annual cycle occurs;

nnr-The annual cycle of cost;

PWN_ — The annual cost discount factor;

PWS — The salvage value of the discount factor;

$\mathrm{S}$ - The salvage value;

If you need to consider partial project unit price, That predict engineering estimate and budget for the sum of partial project unit cost. Calculation formula is shown below:

$$
\begin{aligned}
\mathrm{LCC}= & S^{\prime} \sum_{i=1}^{n}\left[\alpha_{1 i} \beta_{1 i} T_{1 i} D_{1 i}+\alpha_{2 i} \beta_{2 i} T_{2 i} D_{2 i}\left(1-T_{1 i}\right)+\alpha_{3 i} \beta_{3 i} T_{3 i} D_{3 i}\left(1-T_{1 i}\right)\left(1-T_{2 i}\right)\right]+ \\
& S^{\prime} \sum_{i=1}^{n}\left(\frac{\left(1-T_{1 i}\right)\left(1-T_{2 i}\right)\left(1-T_{3 i}\right)\left(\alpha_{1 i} \beta_{1 i} T_{1 i}+\alpha_{2 i} \beta_{2 i} T_{2 i}+\alpha_{3 i} \beta_{3 i} T_{3 i}\right)}{3}\right)+S^{\prime} P W A \sum_{j=1}^{n} A_{j}+ \\
& \sum_{k=1}^{n n r} C_{k} P W C N_{k}-P W S \times S
\end{aligned}
$$

In the formula, $S$ - The architectural area of the proposed project;

$\alpha_{n i}-$ Location adjustment coefficient;

$\beta_{n i}-$ The adjusted factor based on time;

$T_{n i}$ - The degree of similar engineering;

$D_{1 i}, D_{2 i}, D_{3 i} \longrightarrow$ Division component project unit price of the three most similar engineering compared with the case of a partial project $i$;

PWA — The annual cycle cost of the discount factor;

nar- The cost of several year cycle;

A — The annual cycle of cost;

$\mathrm{C}$ - The cost of the annual cycle occurs;

nnr- The annual cycle of cost;

PWN — - The annual cost discount factor;

PWS _ The salvage value of the discount factor;

$\mathrm{S}$ - The salvage value;

We can prepare the plan of investment in fixed assets according to the whole life cycle engineering cost sharing information. We also can analyze the construction cost and the unit production capacity by reference to it. It can also be used as the basis for preparation of investment estimation, preparation of preliminary design, review the construction drawing

budget (Qiaoting Dong, 2013). He can also be used as a basic data to determine the tender price control, and to prepare the quota. We also adjust the coefficient can be determined using them, prepare the cost index, study the changing rule of the construction cost.

\section{CONCLUSION}

We study the whole life cycle engineering cost information data through applying the computer information technology and mathematics model, and to development and utilization of the project cost information resource. To build the whole life cycle engineering cost information data index system, to create information sharing platform, we can estimate the whole life cycle of projects to the project cost by using mathematical model. Quantitative analysis of the history of the engineering cost information, and consider the factor of construction time and construction site, we can predict the project construction cost, operation cost and maintenance cost. We also can dynamically control and optimization of whole life cycle engineering cost management. 
Table 2. Longitudinal monitoring analysis indicators design in the same project

\begin{tabular}{|c|c|c|c|}
\hline $\begin{array}{c}\text { Construction engineer- } \\
\text { ing }\end{array}$ & The difference & ratio & instructions \\
\hline Investment estimation & $\begin{array}{l}\text { Investment estimation } \\
\text {-Roughly estimated at } \\
\text { the design stage }\end{array}$ & $\begin{array}{c}\text { (Investment estimation } \\
\text {-Roughly estimated at the design } \\
\text { stage)/ Investment estimation }\end{array}$ & \multirow{5}{*}{$\begin{array}{l}\text { Conclusion: Positive said } \\
\text { saving, Negative value to } \\
\text { save; Said saving of ab- } \\
\text { solute value, The size of } \\
\text { relative value to save }\end{array}$} \\
\hline $\begin{array}{l}\text { Roughly estimated at } \\
\text { the design stage }\end{array}$ & $\begin{array}{l}\text { Roughly estimated at } \\
\text { the design stage } \\
\text {-The bidding price con- } \\
\text { trol }\end{array}$ & $\begin{array}{l}\text { (Roughly estimated at the design } \\
\text { stage } \\
\text {-The bidding price control)/ Roughly } \\
\text { estimated at the design stage }\end{array}$ & \\
\hline $\begin{array}{c}\text { The bidding price con- } \\
\text { trol }\end{array}$ & $\begin{array}{l}\text { The bidding price con- } \\
\text { trol } \\
\text {-The contract price }\end{array}$ & $\begin{array}{c}\text { (The bidding price control } \\
\text {-The contract price)/ The bidding } \\
\text { price control }\end{array}$ & \\
\hline The contract price & $\begin{array}{l}\text { The contract price- } \\
\text { Completion and settle- } \\
\text { ment }\end{array}$ & $\begin{array}{c}\text { (The contract price- } \\
\text { Completion and settlement)/ The con- } \\
\text { tract price }\end{array}$ & \\
\hline $\begin{array}{l}\text { Completion and settle- } \\
\text { ment }\end{array}$ & & & \\
\hline
\end{tabular}

Table 3 Lateral comparison analysis indicators design similar project

\begin{tabular}{|c|c|c|c|}
\hline $\begin{array}{l}\text { Construction engineer- } \\
\text { ing }\end{array}$ & The difference & ratio & instructions \\
\hline The unit cost & $\begin{array}{l}\text { The social average unit } \\
\text { cost-The unit cost }\end{array}$ & $\begin{array}{l}\text { The social average unit cost-The unit } \\
\text { cost/ The social average unit cost }\end{array}$ & \multirow{4}{*}{$\begin{array}{c}\text { Conclusion: Save is } \\
\text { value, Negative value } \\
\text { overruns; The absolute } \\
\text { value said saving and } \\
\text { cost overruns, The size } \\
\text { of relative said spare and } \\
\text { cost overruns }\end{array}$} \\
\hline $\begin{array}{l}\text { Unit volume of em- } \\
\text { ployment }\end{array}$ & $\begin{array}{l}\text { Average unit man-days } \\
\text { consumption society- } \\
\text { Unit volume of em- } \\
\text { ployment } \\
\end{array}$ & $\begin{array}{l}\text { Average unit man-days consumption } \\
\text { society- Unit volume of employment/ } \\
\text { Average unit man-days consumption } \\
\text { society }\end{array}$ & \\
\hline $\begin{array}{l}\text { The unit consumption } \\
\text { of the main materials }\end{array}$ & $\begin{array}{l}\text { Social average main } \\
\text { material consumption- } \\
\text { The unit consumption } \\
\text { of the main materials }\end{array}$ & $\begin{array}{c}\text { Social average main material con- } \\
\text { sumption- The unit consumption of } \\
\text { the main materials/ Social average } \\
\text { main material consumption }\end{array}$ & \\
\hline $\begin{array}{l}\text { The unit consumption } \\
\text { of the major mechani- } \\
\text { cal machine-team }\end{array}$ & $\begin{array}{l}\text { The main mechanical } \\
\text { affecting social average } \\
\text { consumption- The unit } \\
\text { consumption of the ma- } \\
\text { jor mechanical ma- } \\
\text { chine-team }\end{array}$ & $\begin{array}{l}\text { The main mechanical affecting social } \\
\text { average consumption- The unit con- } \\
\text { sumption of the major mechanical } \\
\text { machine-team/ The main mechanical } \\
\text { affecting social average consumption }\end{array}$ & \\
\hline
\end{tabular}

Table 4 The stage division and the precision requirement of the project investment estimation

\begin{tabular}{|l|l|l|}
\hline phase & content & $\begin{array}{l}\text { Investment esti- } \\
\text { mation accuracy } \\
\text { requirements of } \\
\text { error is allowed }\end{array}$ \\
\hline $\begin{array}{l}\text { The first } \\
\text { stage }\end{array}$ & Project investment ideas & $> \pm 30 \%$ \\
\hline $\begin{array}{l}\text { The second } \\
\text { stage }\end{array}$ & $\begin{array}{l}\text { Project investment op- } \\
\text { portunity study period }\end{array}$ & $-30 \% \sim 30 \%$ \\
\hline $\begin{array}{l}\text { The third } \\
\text { stage }\end{array}$ & $\begin{array}{l}\text { Preliminary project fea- } \\
\text { sibility study period }\end{array}$ & $-20 \% \sim 20 \%$ \\
\hline $\begin{array}{l}\text { The fourth } \\
\text { stage }\end{array}$ & $\begin{array}{l}\text { Project feasibility study } \\
\text { period in detail }\end{array}$ & $-10 \% \sim 10 \%$ \\
\hline $\begin{array}{l}\text { The fifth } \\
\text { stage }\end{array}$ & $\begin{array}{l}\text { Project engineering de- } \\
\text { sign stage }\end{array}$ & $-5 \% \sim 5 \%$ \\
\hline
\end{tabular}

\section{REFERENCES}

Bing Feng, Jianzhong Zhang. Design index system of technical and economic analysis of project cost information accumulation and Exploration in the application of EXCEL[J]. Journal of Inner Mongolia University of technology.2005 (11).

Dong Jin, Wei Fajie. A Study on Life Cycle -Oriented Analysis Method of Project Cost [J].The 1st International Conference on Information Science and Engineering (ICISE2009):41534157.

Jie Ni,Fu Xiang. High-rise residential steel con-tent of research Based on the SVM[J]. Building economy, 2013(6):46-54.

Lu Yu, Wenying Pu. Engineering cost information of the application and prospect[J]. Building econo-my, 2013(6):35-36.

Qiaoting Dong. Based on the information of railway investment control strategy and system framework[J]. Building economy, 2013(7):48-51.

Qin Lin. Preparation of engineering cost index are discussed[J]. Building economy, 2005(2):67-68.

Shibo Dong, lixin Zheng. The whole life cycle cost of the project cost analysis model[J].9th Pacific As-sociation of Quantity Surveyors congress.2005. 